\title{
Lecturers' Perceptions of Open-Plan Office in Tertiary Institutions
}

\author{
Christianah Oluwatoyin Oyetunji (Corresponding author) \\ Limkokwing University of Creative Technology, Botswana, E-Mail: ctoyetunji@yahoo.co.uk
}

Received: October 19, 2013 Accepted: November 7, 2013 Published: November 30, 2013

doi:10.5296/jet.v1i1.4644ＵRL: http://dx.doi.org/10.5296/jet.v1i1.4644

\begin{abstract}
This paper describes and assesses lecturers' perceptions of open-plan office in selected tertiary institutions in Botswana. A structured questionnaire was used to collect data from 222 randomly selected lecturers who were occupants of open-plan office in three different private tertiary institutions in Botswana. The results showed that lecturers have a negative perception of open-plan office. Lecturers believed that open-plan office is not suitable for their research and academic work. The findings suggest that open-plan office affects lecturers' dignity negatively. Among other things, it is recommended that management of the institutions covered by this study and other institutions with similar challenges in Africa should consider the provision of office design that is ideal for knowledge workers such as lecturers in higher institutions in order to improve their efficiency.
\end{abstract}

Keywords: open-plan office, lecturers' perception, dignity at work, tertiary institutions

\section{Introduction}

The provision of a suitable physical work environment for employees is one of the contributing factors to employees' dignity at work and productivity (Newsham et al., 2009; Naseem et al., 2011; Gensler, 2006). Physical work environment refers to offices, cubicles, buildings, and mobile workplaces in which workers perform their work (Davenport, 2005). In recent times the concept of physical work environment has received a lot of attention in organizational management. In the corporate world, it is believed that physical work environment rather than remuneration, accounts for the level of employee's performance on the job most times. This is because the former is believed to have some bearing on employees' error rate, innovation level, absenteeism and turnover rate while the latter has a temporary effect on employees (Chandrasekar, 2011).

Several attempts made to relate the physical environment with workers' productivity sums up into two major classifications: office layout and office comfort. The office layout seems to focus on two ideas: open-plan as opposed to cellular/single offices; suitability of office 
environment to the work processes (Chandrasekar, 2011). There have been debates around open-plan office with regard to its effectiveness in facilitating communication and teamwork among workers (Hameed \& Amjad, 2009) especially at corporate level. In addition, open-plan office is designed to increase flexibility to organizational adjustments and to deal with these adjustments with no reconstruction (Danielson \& Bodin, 2008). A large number of studies have shown that some aspects of open-plan office (e.g. individual privacy, distractions, interruptions and lack of status markers) affect workers' satisfaction negatively while some other environmental factors (e. g. proximity to a window, high partitions, lighting and ventilation/temperature) were found to satisfy occupants of open-plan office (Yildirim et al., 2007; Veitch, et al., 2007; Humphries, 2005; Veitch, et al., 2004).

Despite the positive effects of open-plan office on its occupants, the latter complaints about open-plan office include: loss of status (O’Neil, 2008) noise distraction (Chigot, 2005; DeMarco, 2002) lack of privacy (Mubex, 2010) and health related issues (Charles et al., 2005). Generally, studies on open-plan office tend to focus on corporate organizations and scarcely on educational settings especially in tertiary institutions, notable exceptions being Price and Fortune's (2008) in UK and Baldry and Barnes' (2012) in UK and Australia. The purpose of this study therefore, is to analyze lecturers' perceptions of open-plan office in selected tertiary institutions in Botswana. Hughes' (2007) study of 2000 employees in many organizations with regard to workspace indicated that nine out of ten employees were of the opinion that the quality of a workspace influences employees' attitude and productivity. Thus, it is important to find out the opinions of lecturers who are occupants of open-plan office as part of the effort toward the improvement and sustenance of education standards.

\subsection{Background Information}

Hughes' (2007) finding was supported by Mike (2010) who asserted that a better workplace environment produces better results. The promotion of open-plan office in corporate organizations has been linked to its effectiveness in enhancing social interaction, communication flow and teamwork among employees. The same effect has not been established in knowledge organizations such as tertiary institutions of learning (Baldry \& Barnes, 2012). Despite the downsides of open-plan office, academic staff in some Botswana tertiary institutions perform teaching and related activities which require concentration such as lesson preparation, drafting and marking of tests and examinations and compilation of marks, and one-on-one consultation with students in open-plan offices.

Lecturers are among the group of employees classified as knowledge workers whose work uses mental faculty and involves the use of information, creativity and decision making (Mohanta, 2010). Knowledge workers prefer closed/cellular office because it allows them to enjoy uninterrupted concentration required by the nature of their work (Davenport, 2005), which open-plan office design does not cater for (Myerson \& Bichard, 2010). Research finding showed that less distractions increases workers' productivity (Ajala, 2012).

As earlier indicated in this paper, many of the studies on open-plan office focused on corporate setting (Davenport, 2005; Myerson \& Bichard, 2010: Veitch, Charles, Kelly, Farley, $\&$ Newsham, 2007). Furthermore, the few studies on open-plan office that focused on 
academic setting were undertaken in UK and Australia. For example, based on the evidence that some academics identified distractions of open-plan office as a source of stress (Court \& Kinman, 2008), an exploration study was undertaken by (Baldry \& Barnes, 2012), to examine the introduction of open-plan office in United Kingdom and Australia higher institutions of learning.

One of the major reasons of introducing open-plan office in higher institution setting is because it is cost effective, but to many academics in Australia and United Kingdom open-plan academic office is "detrimental to both scholarship and professional identity" (Baldry \& Barnes, 2012). Pinder, Parkin, Austin, Duggan, Lansdale, Demian et al.'s (2009) research findings suggest that little attempt has been made to match 'accommodation to the specific nature of the academic work involved, or to academic work in general'. Again, evidence from research indicates that open-plan office is not suitable for professional and 'think work' (Bosch-Sijtsema et al., 2010; Hedge, 1982) it is almost impossible to do cognitive-based work such as research or marking in open-plan office (Baldry \& Barnes, 2012). One observes therefore that research that focused on open-plan office within the academic set up in Africa is very rare, hence the attempt made in this paper to examine the perception of lecturers in selected tertiary institutions in Botswana. The result of the research will be of immense value to human resource management in tertiary institutions in Botswana and in Africa as a whole.

\section{Related Literature}

\subsection{Open-Office}

The idea of open-plan office started in Germany in the late 1950's and was embraced in the United States of America in the 1960's (Hundert \& Greenfield, 1969). By mid-1970 open offices became familiar in North America, and continues to be the main kind of office plan. It was believed that open office is cost-efficient compared to cellular office, provided various administrative, fiscal and working condition benefits like easy communication between departments, space reduction (as corridors are left out) and improved general environmental condition of open office (Hundert \& Greenfield, 1969; Zalesny \& Farace, 1987). Open-plan office is characterized by the absence of walls and partitions. In line with Chandrasekas' (2011) observation, Vietch, et al. (2007) findings showed that workers who work in and are happy with open-plan office show more fulfillment in their jobs.

An open-plan office is depicted by employees sharing a common workspace with neither walls between workstations nor access to personal windows. In order to minimize noise and create some privacy there are partitions between workstations (Danielson \& Bodin, 2008). This study uses Christiansson and Eiserman's (1998) description of the medium-sized open-plan office which contains 10 to 24 people per room, and Danielson and Bodin's (2008) picture of the large open-plan office which contains more than 24 people per room. This is because many of the respondents in this study are occupants of open-plan offices similar to the description above; only a few of them occupy offices that contain less than ten people. The description of the medium-sized and large open-plan offices is similar to the offices occupy by the participants in this study. It is important to note that there are no partitions 
between workstations in the open-plan offices investigated in this study.

A number of studies on work environment indicate that some workspace features are crucial to workers' productivity and workspace satisfaction. Some examples of such features are: ventilation rates (Charles et al., 2005), and level of privacy, lighting, natural light and acoustic environment. Yildirim, et al. (2007) assessed the impact of nearness to a window and open-plan workstation partition height on employee satisfaction. The findings indicated that nearness of workspace to a window and up to 60 inches high partition increased employee's contentment.

A typical office is designed based on the nature of job or business activities and employees that will work in that office (Mike, 2010). O'Neil's (2008) study on workspace type preferences of high technology workers indicated that the work type and type of work the individual does informed workers preference for open or enclosed work environments. Computer programmers for example, who tend to work as a team, preferred open-plan workstations with moderately high partitions whereas software developers and engineers, whose work is likely to demand higher levels of concentration and no distraction, preferred either a private office with a door or open- plan environments with very high partitions. There is research evidence that software developers who work in spaces characterized by less noise distractions perform far better compared to their colleagues who work in environments where they could be more easily disturbed by noise (DeMarco, 2002).

According to Vischer (2005), office type connotes status marker. Similarly, reporting the findings of a study, O'Neil (2008) stated that more than 50\% of the participants asserted that a closed office is a marker of higher status, a place of dignity compared to open-plan workspaces. The same research showed that the majority of employees relocating from closed office to an open-plan workstation sense a depletion of status and benefits. Although the idea of office type as status maker may have been overtaken by events (technology devices) it may be one of the contributing factors why some workers resist open-plan office (Price \& Fortune, 2008).

Because office type is capable of giving workers a sense of personal control, it may predict workers' fitness and welfare (Danielsson \& Bodin, 2008). Danielsson and Boding's (2008) research findings which suggest that office type has significant effect on employee's health status and general well-being support the above statement. It was also found that employees who are occupants of cellular offices are the most satisfied with their office environments and that compared to employees in various sizes of open-plan offices, cellular office occupants are most likely to enjoy wholesome health.

\subsection{Dignity at Work}

Dignity entails respecting, treating and appreciating employees as people in themselves rather than what can be achieved by means of them. It also shows in how employees interact with one another (Sayer, 2007; Lucas, 2011). Sayer (2007) maintained that compared to low pay or job security, employees can find disrespectful more difficult to bear. Thus, the concept of dignity at work is important to both employees and employers and should be given due 
attention (Cheney, Zorn, Planalp, \& Lair, 2008).

Dignity at work does not only indicate absence of harassment and bullying at workplace, it also includes other issues such as good terms and conditions of employment, respectful social atmosphere, and physically healthy working environment (Sayer, 2007). Furthermore, Sayer (2007) pointed out that to have dignity is to be in charge of one's situation, being able to use one's powers without unnecessary restrictions. It is about being independent to do what one considers appropriate as an employee. Bolton (2007) argued that any act that distresses employees is a reflection of lack of dignity at workplace. Dignity has to do with employees' emotions and other conditions which have effect on their well-being, these include: 'integrity, respect, pride, recognition, worth and status' all of which are correlated with dignity (Sayer, 2007). As a result, it is important that organizations provide working environment that supports autonomy, 'equity, security and human dignity' as advocated by (International Labour Office, 2008a).

\section{Methodology}

\subsection{Research Questions}

This paper examines lecturers' perceptions of open-plan office. Two research questions guided the research, they are the following:

- What are lecturers' perceptions of open-plan office in tertiary institutions?

- What is the effect of open-plan office on lecturers' dignity at work?

\subsubsection{Participants}

A total of 252 lecturers who were occupants of open-plan offices participated in this study. The majority of the lecturers were master's degree holders in various disciplines. The participants were randomly selected from three of the four private tertiary institutions in Botswana. All the participants responded to a questionnaire of 39 items.

\subsubsection{The Instrument}

A questionnaire with three sections (A-C) was used in this study. Section A consists of questions that elicited socio-demographic characteristics respondents such as gender and age. Section B consists of items on open-plan office and section C contains items that elicited dignity at work. Responses to the items were made on a self-rating, five-point Likert scale ranging from 'Strongly Disagree' to 'Strongly Agree'.

\subsubsection{Data Collection}

In this research, a total of 252 questionnaires were distributed to randomly selected lecturers from some Botswana tertiary institutions 239 questionnaires were returned. Because some of the respondents did not complete the questionnaire, 222 questionnaires (88\%) were used for data analysis. They were 121 males and 101 females. The participants responded to 35 items on open-plan office and 4 items on dignity at work. 


\subsubsection{Data Analysis}

Frequencies, cross-tabulations and chi-square were used to analyze the collected data. The items of the questionnaires were analyzed using the IBMSPSS statistics version 21 according to the five point Likert scale as follows: (1) strongly disagree, (2) disagree, (3) undecided, (4) agree, and (5) strongly agree. Thereafter, the basic descriptive statistics (means and standard deviations) as well as Chi-square were computed. Chi-square was used to look for relationships between the variables. The significance level in this study was set at $\mathrm{p}=0.05$.

\section{Results}

Table 1. Respondents' perception of open-plan office

\begin{tabular}{|l|l|l|l|}
\hline Open-plan office elements & Agree & Undecided & Disagree \\
\hline Inclination to work in an open-plan office & $23(10 \%)$ & $25(11 \%)$ & $174(78 \%)$ \\
\hline No Distraction & $25(11 \%)$ & $22(10 \%)$ & $175(79 \%)$ \\
\hline Users have privacy & $10(4 \%)$ & $17(8 \%)$ & $195(88 \%)$ \\
\hline Users have control over space and work life & $62(28 \%)$ & $56(25 \%)$ & $104(47 \%)$ \\
\hline Personal items are safe & $17(8 \%)$ & $25(11 \%)$ & $180(81 \%)$ \\
\hline Enhances group cohesiveness & $149(67 \%)$ & $45(20 \%)$ & $28(13 \%)$ \\
\hline Eliminates social status & $62(28 \%)$ & $35(16 \%)$ & $125(56 \%)$ \\
\hline Satisfaction with workplace & $17(8 \%)$ & $39(17 \%)$ & $166(75 \%)$ \\
\hline
\end{tabular}

The first research question was: What are lecturers' perceptions of open-plan office in tertiary institutions? The results as shown in Table 1 indicate that a good number of the respondents experience distraction, thus they struggle to concentrate in this type of office design. Many of them believe that there is no privacy in an open-plan office and almost half of the lecturers think they neither have control over their work space nor work life. Many of the respondents believe that their personal belongings are not safe in this kind of office. However, many also are of the opinion that open-plan office gives them the opportunity to interact freely with their colleagues. More than half of the lecturers felt that open-plan office does not eliminate social status. Many of the lecturers are not satisfied with their work environment. Thus, it can be inferred that many of the lecturers have a negative perception of the open-plan office.

To answer the second question: What is the effect of open-plan office on lecturers' dignity at work? Chi-square was calculated to examine the relationship between the elements of open-plan office and dignity at work. The variables were tested at $5 \%$ level of significance. 
The results suggest that there is very strong relationship between inclination to work in an open office and satisfaction with work place and dignity at work. The $\mathrm{P}$ - values range from 0.000 to 0.008 indicating very strong associations between the variables of the different categories. Dignity at work is strongly related to satisfaction with the workplace, inclination to work in an open-plan office, distraction, control over work space, safety of personal belongings, elimination of social status and interaction in an open-plan office.

\section{Discussion of the Findings}

From the findings many lecturers have a negative perception towards working in an open-plan office. This shows that an open-plan office is not a conducive environment for lecturers. The lecturers working in an open-plan office are not happy with the environment in which they work. Almost all of them (90\%) disagreed to one of the open-plan questionnaire items which suggest the idea that an open-plan office is as good as a closed office in tertiary institutions. There are several reasons for this. Firstly, lecturers believe that there is no privacy in open-plan offices. Personal information and belongings are not safe when several people share an office. Private conversations either on phone or with colleagues are heard by others in the office. In addition, it becomes difficult when the need arises for lecturers to have counseling sessions with individual students. When many people share an office, none of its occupants may be responsible for the key except the Operations Department (as it is the case in this study) if things are missing it will be difficult to hold anybody accountable. Again, if all its users have the key to the office it may not be easy to monitor who is in the office, at what time and doing what? Cases of theft have been reported by some of the lecturers who are the occupants of open-plan offices. A lecturer's laptop and some lecturers' cell-phones have been stolen in a few of the open-plan offices investigated in this study. The stolen items could not be traced to either lecturers who occupy the offices or students who are always in and out of the offices.

Secondly, lecturers experience both visual and auditory distractions in open-plan offices. There are ceaseless movements and conversations of students and colleagues which cannot be controlled. Besides, some lecturers play music on their laptops, different sounds from cell-phone ringing tones and some lecturers talk loud on cell-phone making open-plan offices noisy. Planning and conducting researches in preparation for lectures are necessary for lecturers to do quality work in class. A picture of an office characterized by the above mentioned issues may be a hindrance to conducting a research either in preparation for lectures or for personal development. Thus, a rowdy or noisy office does not promote mental concentration required for lecturers' type of work. In effect, sharing an office with many colleagues may restrict lecturers' efficiency and discourage their efforts toward professional development. When many people of diverse characters and values share an office; the likelihood is that a few of them may sometimes display unprofessional behaviours, such as lack of respect for colleagues and or shared facilities.

Thirdly, the issue of control over work space and work life in open-plan offices is not that straightforward. The number of lecturers who claimed to have some sort of control is the same number of lecturers who did not think that their work space and life is under their 
personal control. This suggests that lecturers have control over their work space and life but to a limited extent. They can to some extent, make some rearrangements to their work space/area and make some work related decisions. Lastly, the findings suggest that an open-plan office does not eliminate social status. Although majority of the respondents are master's degree holders, a few of them have doctorate degree while some have first degree certificates. Because the lecturers have diverse educational backgrounds, they may have been ascribed different levels of status even within their workplace. It can be inferred that some lecturers who differ from others in terms of educational attainments are cautious in relating with other colleagues. Consequently, many lecturers do not believe that open-plan office eliminates social status within the workplace.

Nevertheless, similar to what is reported in the literature, it is very clear from the findings of this study that an open-plan office enhances communication flow and interaction among its occupants. An open-plan office provides opportunities for lecturers to mingle with one another and enhances team work. The absence of workstation partitions and the use of common facilities facilitate the free flow of communication among lecturers and easy access to each other's workspace/workstation. Official and unofficial information travels fast and occupants get easily acquainted with one another in an open-plan office. Thus, open-plan increases the opportunity for social interaction among lecturers. It is important to note that out of all the elements of open-plan office, social interaction is the only element that lecturers perceived as a favorable attribute of an open-plan office. Because lecturers share an office when they are at work, the tendency is that they learn to adjust to one another's needs and character in order to work together as a team thereby improving relationships amongst them.

A strong relationship between dignity at work and open-plan elements such as inclination to work in an open-plan office, lack of privacy, lack of safety of personal belongings, satisfaction with workplace and distraction suggest that open-plan office has a significant effect on lecturers' dignity; lecturers are not satisfied with their workplace environment. Similar to Chandrasekas' (2011) findings, lecturers do not feel respected working in open-plan office due to issues associated with the office design. In effect, because lecturers do not enjoy working in open-plan office, the likelihood is that they will not be very committed to their job. When lecturers are unable to do satisfactory planning before they go to class they are not likely to be able to deliver lectures effectively. In addition, lecturers whose workplace environment does not promote personal development may gradually lose their enthusiasm and ultimately desire for professional self-fulfillment.

\section{Conclusions and Implications for Management}

Generally, the findings agree with trends reported in past research studies except for the fact that most of the studies were carried out in corporate settings. The results of this study suggest that lecturers who are occupants of open-plan office have a negative perception of open-plan office. Many of them do not enjoy working in open-plan offices because there are many distractions, there is no privacy, their personal belongings are not safe, they have restricted control of their workspace and their effectiveness is greatly compromised by their work environment. The aforementioned issues which also hinder lectures' personal 
development or advancement have a significant negative effect on lecturers' dignity at work.

Most lecturers believe that open-plan office is not suitable for the kind of job they do. There is need to match job type to office type (Mike, 2010). Lecturers' preference for cellular offices indicates that their type of job requires such design (O'Neil, 2008), open-plan office does not support lecturers' job (Myerson \& Bichard, 2010); they need concentration to be productive (Ajala, 2012) and to accomplish personal career goals. It is therefore imperative to provide lecturers with a suitable office design that will help them to do their job effectively.

The provision of an appropriate office will not only increase lecturers' enthusiasm about their job but it will also give them the opportunity to do one of the major things they require to remain in academia: contribution to knowledge through publications. It is assumed that lecturers who are enthusiastic will go all out to help their students in the acquisition of knowledge; they will provide their students with quality learning materials as a way of improving the prevailing standard of education in Botswana tertiary institutions. Furthermore, a suitable office design is expected to encourage lecturers to embark on projects towards their personal development so as to take their career to higher levels.

It is therefore suggested that the management of tertiary institutions in Botswana and Africa in general should look into the welfare of lecturers with regard to the offices from which they operate. To start with, management in Botswana private tertiary institutions and other tertiary institutions in Africa where lecturers occupy open-plan office should consider using high partitions to separate individual lecturer's workspace to reduce noise, to ensure some sort of privacy (Danielson \& Bodin, 2008) and to improve lecturers' well-being at workplace (International Labour office, 2006). However, the ultimate goal of management in these institutions should be to provide cellular / closed offices for lecturers. In addition, each of these institutions should mount workshops on professionalism for lecturers. This will help many lecturers to be more sensitive to other people around them, by talking in low voices and putting their cellphones on silent while in the office. This kind of workshop will go a long way in reducing the rowdiness and noise level associated with open-plan office in these institutions.

The management of these institutions should provide a room attached to each of the open-plan offices for private discussion purposes. Although there is a counseling unit in these institutions, some students prefer to share their minds with lecturers who they are close to or those they can trust. Thus, lecturers can use the room for individual student who needs counseling. A private room will encourage students to share their challenges without any inhibition. As a result, many students can be assisted to overcome things that prevent them from focusing on their studies. In the long run, it can improve class attendance, students' performance and their general perception of life. These institutions should consider developing well-defined guidelines that can be used to select and support / sponsor employees for various professional development opportunities.

\subsection{Limitations of the Study}

The following are a few limitations of the study: 
The data collected was based only on self-report measurement; some other subjective data collection methods (e. g. interviews and observation) can also be used in addition to self-report.

\section{References}

Ajala, E. M. (2012). The influence of workplace environment on workers' welfare, performance and productivity. The African Symposium, 12(1), 141-149.

Baldry, C., \& Barnes, A. (2012). The open-plan academy: space, control and the undermining of professional identity. Work, Employment and Society, 26(2), 228-245. http://dx.doi.org/10.1177/0950017011432917

Bolton, S. C. (2007). Dignity in and at work: why it matters. In S. C. Bolton (Ed.), Dimensions of dignity at work. Oxford: Elsevier, 1-16.

Bosch-Sijtsema, P. M., Ruohomäki, V., \& Vartiainen, M. (2010). Multi-locational office workers in the office: navigation, disturbances and effectiveness. New Technology Work and Employment, 25(3), 183-95. http://dx.doi.org/10.1111/j.1468-005X.2010.00247.x

Chandrasekar, K. (2011). Workplace environment and its impact on organizational performance in public sector organizations. International Journal of Enterprise Computing and Business System, (1), 1-19.

Charles, K., Reardon, J. T., \& Magee, R. J. (2005). Indoor air quality and thermal comfort in open-plan offices. Construction Technology Update, 64, 1-7.

Cheney, G., Zorn, T. E., Planalp, S., \& Lair, D. J. (2008). Meaningful work and personal/social well-being: Organizational communication engages the meanings of work. In C. S. Beck (Ed.), Communication yearbook, 32, 137-185. New York: Routledge.

Chigot, P. (2005). Effects of sound in offices: subjective experience vs. objective assessment. Facilities, 23(3/4), 152-63. http://dx.doi.org/10.1108/02632770510578520

Christiansson, C., \& Eiserman, M. (1998). Framtidens kontor- kontorets framtid (The office of the future- the future for the office) (32 ed.). Laholm: Byggförlaget.

Court, S., \& Kinman, G. (2008). Tackling stress in higher education. London: University and College Union.

Danielsson, C., \& Bodin, L. (2008). Office type in relation to health, well-being, and job satisfaction among employees. Environment and Behavior, (40), 636-668. http://dx.doi.org/10.1177/0013916507307459

Davenport, T. H. (2005). Thinking for a living: how to get better performances and results from knowledge workers. Cambridge, MA: Harvard Business Press.

Demarco, T. (2002). Slack: Getting past burnout, busywork and the myth of total efficiency. New York: Random House.

Hameed, A., \& Amjad, S. (2009). Impact of office design on employees' productivity: A case 
study of banking organisations of Abbotttabad, Pakistan. Journal of Public Affairs, Administration and Management, 3(1), 2009. Retrieved from: http://www.scientificjournals.org/journals2009/articles/1460.pdf

Hedge, A. (1982). The open-plan office: A systematic investigation of employee reactions to their work environment. Environment and Behavior, 14(5), 519-542. http://dx.doi.org/10.1177/0013916582145002

Huges, J. (2007). Office design is pivotal to employee productivity. Sandiego Source, The daily Transcript, July, 2007.

Humphries, M. (2005). Quantifying occupant comfort: Are combined indices of the indoor environment practicable? Building Research and Information, 33(4), 317-325. http://dx.doi.org/10.1080/09613210500161950

Hundert, A. T., \& Greenfield, N. (1969). Physical space and organizational behavior: A study of an office landscape. Proceedings of the 77th Annual Convention of the American Psychological Association, 4, 601-602.

International Labour Office. (2008a). Decent Work: A Better World Starts Here, ILO, Geneva. Retrieved from: http://www.ilo.org/global/About_the_ILO/Mainpillars/WhatisDecentWork/lang_en/index.htm

Lucas, K. (2011). Blue-Collar discourses of workplace dignity: using outgroup comparisons to construct positive identities. Management Communication Quarterly, 25(2), 353-374. http://dx.doi.org/10.1177/0893318910386445

Mike, A. (2010). Visual workplace: How you see performance in the planet and in the office. International Journal of Financial Trade, 11(3), 250-260.

Mohanta, G. C. (2010). Knowledge worker characteristics and knowledge worker productivity determinants. Retrieved from: http://shodhganga.inflibnet.ac./inbitstream/10603

Mubex, C. M. (2010). Closed offices versus open plan layout. Retrieved September14, 2013, from http://www.mubex.com/sme/closed-vs-open-plan-officers.htm

Myerson, J., \& Bichard, J. (2010). Welcoming workplace: rapid design intervention to determine the office environment needs of older knowledge workers. In T. Inns (Ed.), Designing for the $21^{\text {st }}$ Century: Interdisciplinary Methods and Findings. England: Gower Publishing Limited, 208-224.

Naseem, A., Sheikh, S. E., \& Malik, K. P. (2011). Impact of employee satisfaction on success of organization: relation between customer experience and employee satisfaction. International Journal of Multidisciplinary Sciences and Engineering, 2(5), 41-46.

Newsham, G., Brand, J., Donnelly, C., Veitch, J., Aries, M., \& Charles, K. (2009). Linking indoor environment conditions to job satisfaction: a field study. Building Research and Information, 37(2), 129-147. http://dx.doi.org/10.1080/09613210802710298

O’Neil, M. (2008). Open plan and enclosed private offices: Research review and 
recommendations. NY: Knoll Inc.

Pinder, J., Parkin, J., Austin, S., Duggan, F., Lansdale, M., \& Demian, P. (2009). The Case For New Academic Workspaces. Loughborough: Department of Civil and Building Engineering, University of Loughborough.

Price, I., \& Fortune, J. (2008). Open plan and academe: pre- and post-hoc conversations. In D. S. S. Then \& E. Finch (Eds.) Proceedings of the W070 conference: healthy and creative facilities. CIB publication (315). CIB, 613-620.

Sayer, A. (2007). What dignity at work means. In S. C. Bolton (Ed.), Dimensions of dignity at work (pp. 17-29). Oxford: Elsevier.

The Gensler+Performance Index. The U.S. Workplace Survey (2006). Retrieved August, 2013, from http://www.gensler.com

Veitch, J. A., Charles, K. E., \& Newsham, G. R. (2004). Workstation design for the open-plan office. Construction Technology Update, 61, 1-6.

Veitch, J., Charles, K., Kelly, Farley K., \& Newsham, G. A. (2007). Model of satisfaction with open-plan office conditions: COPE field findings. Journal of Environmental Psychology, 27(3), 177-189. http://dx.doi.org/10.1016/j.jenvp.2007.04.002

Vischer, J. (2005). Space meets status: Designing workplace performance. London: Routledge.

Yildirim, K., Akalin-Baskaya, A., \& Celebi, M. (2007). The effects of window proximity, partition height, and gender on perceptions of open-plan offices. Journal of Environmental Psychology, 27(2), 154-165. http://dx.doi.org/10.1016/j.jenvp.2007.01.004

Zalesny, M. D., \& Farace, R. V. (1987). Traditional versus open offices: A comparison of sociotechnical, social relations, and symbolic meaning perspectives. Academy of Management Journal, 30, 240-259. http://dx.doi.org/10.2307/256272

\section{Copyright Disclaimer}

Copyright reserved by the author(s).

This article is an open-access article distributed under the terms and conditions of the Creative Commons Attribution license (http://creativecommons.org/licenses/by/3.0/). 